\title{
Evaluation of Adults' Knowledge on Dental Caries and Oral Habits and Perception on the Oral-Systemic Relationship
}

\author{
Bireylerin Diş Çürüğü Gelişimi ve Oral Hijyen Alışkanlıkları \\ Hakkındaki Bilgi Düzeyleri ile Genel Sağlık-Ağız ve Diş Sağlığı \\ ilişsisinde Farkındalık Düzeylerinin Değerlendirilmesi
}

\author{
(D) Uğur Erdemir ${ }^{1}$, (D) Günçe Ozan ${ }^{1}$, (D) Levent Emir Güneysu², (D) Esra Yıldız ${ }^{1}$ \\ 'İstanbul University Faculty of Dentistry, Department of Restorative Dentistry, İstanbul, Turkey \\ ${ }^{2}$ Private Dental Clinic, İstanbul, Turkey
}

Keywords

Dental caries, oral hygiene, oral health, toothbrushing, demographic and health surveys

\section{Anahtar Kelimeler}

Diş çürükleri, ağız hijyeni, ağız sağlığı, diş fırçalama, demografik ve sağlık anketleri

Received/Geliş Tarihi : 13.08 .2020

Accepted/Kabul Tarihi : 16.10.2020

doi:10.4274/meandros.galenos.2020.60783

Address for Correspondence/Yazışma Adresi: Uğur Erdemir Prof. MD,

İstanbul University Faculty of Dentistry, Department of Restorative Dentistry, İstanbul, Turkey

Phone : +902124142020

E-mail : uerdemir@hotmail.com

ORCID ID: orcid.org/0000-0002-4673-8284

(C) Meandros Medical and Dental Journal, Published by Galenos Publishing House.

This is article distributed under the terms of the

Creative Commons Attribution NonCommercial 4.0

International Licence (CC BY-NC 4.0).

\begin{abstract}
Objective: This study aimed to evaluate the patients' awareness of the relationship between oral and systemic health based on their oral hygiene habits and knowledge. Materials and Methods: A 21-item questionnaire was administered to 500 patients who had been referred to the İstanbul University Department of Restorative Dentistry. The questionnaire consisted of specific questions to evaluate the sociodemographic data and frequency of oral habits and to examine existing systemic diseases. The questionnaires were administered through interviews by the same dentist, and collected data were statistically evaluated using chi-square tests. Results: Of the 500 patients (aged 18-78 years), deficiencies in tooth brushing $(70.6 \%)$ and diet $(50.2 \%)$ were related to dental caries. The effects of inadequate tooth brushing on caries development were not significantly different when analyzed by patients' gender and age groups $(p>0.05)$, whereas significant results were observed in the educational status $(p<0.05)$. Moreover, 19\% of the patients indicated that oral symptoms did not play a crucial role in the early diagnosis of systemic health problems, $41 \%$ stated that it was important, and $40 \%$ had no idea. Patients' awareness of the relationship between oral and systemic health is significantly altered by their educational status $(p<0.001)$.

Conclusion: Knowledge on the relationship between oral and systemic health is inadequate. Thus, patients should be educated on the importance of oral health awareness, as it is an inseparable part of general health. Referrals from health professionals to dentists may improve patients' access to dental care.
\end{abstract}

Öz

Amaç: Bu çalışmanın amacı, bireylerin ağız hijyeni alışkanlıklarına ve diş çürüğü gelişimine ilişkin bilgi düzeylerinin ölçülmesi ve genel sağlık-ağız ve diş sağlığı ilişkisi hakkındaki farkındalıklarının incelenmesidir.

Gereç ve Yöntemler: İstanbul Üniversitesi Restoratif Diş Tedavisi Anabilim Dalı'na başvuran 500 hasta, 21 sorudan oluşan anketi cevaplamıştır. Tüm anketler bir diş hekimi tarafından röportaj şeklinde gerçekleştirilmiştir. Anket, katılımcıların sosyodemografik değerlerini belirlemek, oral alışkanlıklarının sıklığını değerlendirmek 
ve mevcut sistemik hastalıklarını incelemek için ayrıntılı sorular içermiştir. Sonuçlar ki-kare testleri kullanılarak istatistiksel olarak değerlendirilmiştir.

Bulgular: 18-78 yaş arasındaki 500 hastaya göre, yetersiz diş fırçalama $(\% 70,6)$ ve beslenme $(\% 50,2)$ diş çürüğü gelişimi ile direkt ilişkilidir. Yetersiz diş fırçalamanın diş çürüğü gelişimine neden olacağını belirten bireyler, cinsiyet ve yaş grupları açısından anlamlı olarak farklılık göstermezken $(p>0,05)$, eğitim durumları istatistiksel olarak anlamlı farklılık göstermiştir $(p<0,05)$. Katılımcıların \%19'u genel sağlık sorunlarının erken teşhisinde oral semptomların önemli bir rol oynamadığını belirtirken, \%41'i bunun önemli olduğunu belirtmiştir. Bireylerin genel sağlık-ağız ve diş sağlığı ilişkisindeki farkındalık düzeyleri eğitim durumlarına göre anlamlı derecede farklılık göstermiştir ( $p<0,001)$.

Sonuç: Bireylerin genel sağlık-ağız ve diş sağlığı ilişkisi hakkında yeterli bilgiye sahip olmadığı görülmüştür. Ağız-diş sağlığının, genel sağlıktan farklı olarak görülmemesi ve bu bilincin yaygınlaştırılması konusunda bireylerin eğitilmesi gerekmektedir. Bu hususta özellikle sistemik hastalığa sahip olan bireylerin teşhisin ardından tıp hekiminden, diş hekimine yönlendirilmesi büyük önem taşımaktadır. Sağlık profesyonellerinden diş hekimlerine sevk ile bireylerin dental hizmetlere erişimi kolaylaşacaktır.

\section{Introduction}

According to World Health Organization, dental caries and periodontal pathologies are still the most common diseases all over the world which are affected by lack of oral hygiene habits and dental knowledge (1). In the USA, $85 \%$ of the adults older than 18 years and $44 \%$ of the 5 -year-olds are affected by dental caries (2). Likewise, the rate of dental caries was $73.8 \%$, and periodontal diseases were $62 \%$ among adults aged between 35 and 44 in Turkey (3). As dental problems affect patients without any age or gender exceptions and could only be solved by basic oral hygiene procedures, the higher ratios show a deficiency in promoting oral health. Generally, the prevalence was taken from nationwide surveys so that there could be greater numbers when these surveys investigate only special populations such as patients with systemic diseases.

The Fédération Dentaire Internationale first defended oral health as a fundamental human right and an inseparable part of systemic health in 2013 (4). Then, in 2016, oral health was identified as reflecting the physiological, social, and psychological attributes necessary to a quality life (5). Recent studies proved there are systemic diseases with probable oral symptoms as well as oral diseases that could affect the general condition of the body (6-8). Today, many systemic diseases are connected to oral problems such as cardiovascular diseases (9), diabetes (10), rheumatoid arthritis (11), asthma (12), and respiratory diseases (13). Thus, dentists and physicians should work collaboratively in order to increase patients' quality of life. That approach would ensure the health and economic and social needs of the population.
Furthermore, it is crucial to implant the idea of maintaining optimum oral health to provide better general health; also, good oral knowledge could lead to early diagnosis of oral and systemic diseases. Last but not least, with the knowledge of oral diseases, patients could first change their oral beliefs into actions and later into oral habits.

The aim was to measure the oral behavior, knowledge, and perception of the oral and systemic health relation of a group of dental patients who applied for public dental service. This is the first study evaluating the factors affecting caries development among adults and comparing the results over age, gender, and educational levels. The present survey's hypotheses include the following; (1) There were no significant differences in the knowledge on factors affecting dental caries among participants' gender, age, or educational status; and (2) there was a significant difference in the participants' age, gender, and educational status with regard to their perceptions of oral and systemic health.

\section{Materials and Methods}

The present cohort study was designed as a survey and was approved by the Clinical Research Ethics Committee of İstanbul University İstanbul Faculty of Medicine (decision no: 416, date: 16.04.2013).

\section{Subjects}

A sample size of 471 was calculated based on the probable knowledge rate of $20 \%$ on oral-systemic health relation with a margin error of $5 \%$ (confidence interval of $95 \%$ ) using the $G *$ Power program (G*Power v3.1.9.2., Heinrich-Heine-Universität, Düsseldorf, Germany). Regarding the probable missing data and exclusions, the total number of the subjects was 
determined as 500 . The present study was conducted between April and June of 2013 at İstanbul University Faculty of Dentistry. Subjects aged between 18 and 78 were included in the study from whom applied to department of restorative dentistry clinics. Pregnants, lactating mothers and patients with emergency had excluded from the study. Written consents from participants had taken and kept in files separated for each one.

\section{Questionnaire}

21-item surveys (Appendix 1) were prepared. Surveys consisted of detailed questions to investigate the socio-demographic values of the patients such as age, gender and occupation in the first part. In the second part, there were questions on subjects' own oral habits, existing systemic diseases and daily medicaments. The last part was aimed to measure awareness of their own oral health and to understand participants' oral knowledge on caries development and the relation between oral and systemic health. All surveys were carried out as interviews by the same dentist and numbered in a sequel.

\section{Statistical Analysis}

All data with no missing answers were delivered to Microsoft Excel program at first then evaluated by SPSS 17.0 (SPSS Inc., Chicago, IL, USA). Frequencies and percentages were used while analyzing and comparisons were evaluated by chi-square exact test. The significance was adjusted to $p<0.05$.

\section{Results}

Table 1 shows participants' demographic data. Among 500 patients, the average age was found to be $34.5 \pm 13.5$. The number of female $(50.6 \%)$ and male $(49.4 \%)$ subjects were similar with no statistical difference $(p>0.05)$.

Of the 500 subjects, $240(48 \%)$ reported brushing their teeth once a day, 176 (35\%) brushed their teeth 2 or 3 times a day, and $34(7 \%)$ brushed only once a week. Among all participants, 34 (8\%) of them brushed irregularly, and $9(2 \%)$ of them never brushed (Figure 1). Most of the subjects (86\%) did not attend routine dental recalls or use dental floss. Evaluating their toothpaste choices, subjects specified that they rely on their own experiences (35\%) rather than dentists (28\%).

Of the subjects, $55.4 \%$ had gingival bleeding while brushing, and $44.6 \%$ had spontaneous gingival bleeding. To add more, $46.6 \%$ of the subjects had a toothache in the last 6 months. In the last 6 months, $24.8 \%$ of the subjects had tooth scaling.

According to the data, most of the subjects specified that inadequate tooth brushing (70.6\%) was one of the main factors affecting caries development, while diet was the second most reported factor (50.2\%). Participants were asked about their knowledge of factors affecting dental caries, and the majority of subjects were unaware of the effective factors other than tooth brushing (Figure 2).

Table 2 summarizes the multiple comparisons on subjects' knowledge on factors of caries development and their demographic data.

According to Table 2, participants, who determined "genetics" as a factor for caries development, were significantly different in terms of their gender, educational status and age. Age was not also a significant parameter among participants who

\begin{tabular}{|c|c|}
\hline Characteristics & Number (\%) \\
\hline \multicolumn{2}{|l|}{ Gender } \\
\hline Male & 247 (49.4\%) \\
\hline Female & 253 (50.6\%) \\
\hline \multicolumn{2}{|l|}{ Age } \\
\hline $18-30$ & $229(46 \%)$ \\
\hline $31-50$ & $193(39 \%)$ \\
\hline $51+$ & 78 (15\%) \\
\hline \multicolumn{2}{|l|}{ Education level } \\
\hline Primary school & $123(25 \%)$ \\
\hline Middle school & $37(7 \%)$ \\
\hline High school & 244 (49\%) \\
\hline University & 96 (19\%) \\
\hline
\end{tabular}

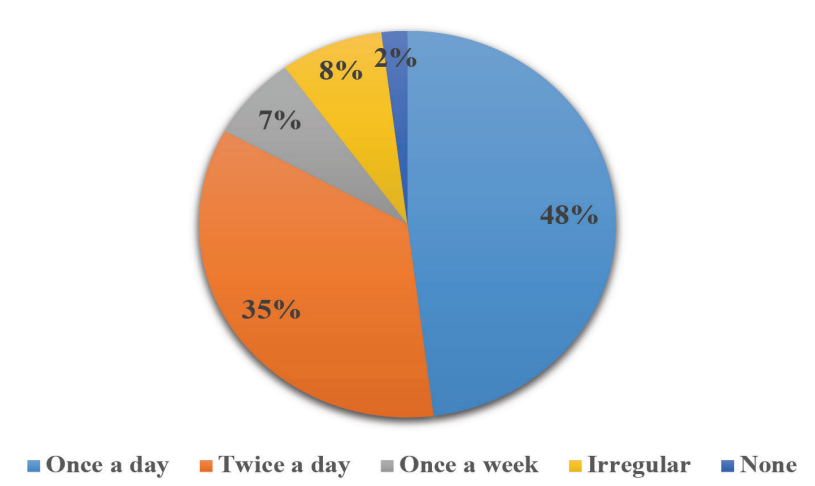

Figure 1. Toothbrushing frequency of the subjects 
described "regular dental visits" as an affecting factor for caries development ( $p>0.05$ ). However, they were different in terms of gender and educational status $(p<0.05)$. Participants determined that "inadequate tooth brushing" is a factor for caries development, and they were statistically significant concerning their educational status only. Diet was found to be a factor for caries development, and it was highly significantly different among participants' gender $(p<0.001)$. Participants who described that "lack of dental knowledge" may affect their caries development were not significantly different by any of the questioned demographic factors ( $p>0.05$ ).

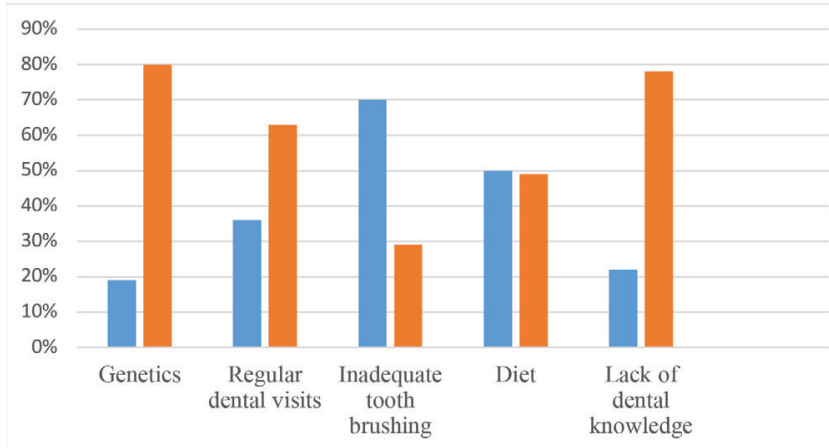

Figure 2. Subjects' knowledge on factors of caries development
The present survey determined that no patients were suffering from multiple sclerosis or any neurological diseases. Table 3 summarizes subjects' situation of systemic diseases and habits. Only $25 \%$ of the subjects with at least one systemic disease had their conditions under a physician's control. Of all the systemically disordered subjects, only $22.2 \%$ had regular medications according to their illnesses. To add more, subjects with systemic diseases or conditions who were visiting their physicians regularly and taking daily medicines had a statistically significant difference compared to those who were not $(p<0.05)$.

Evaluating the awareness and knowledge on the oral symptoms of systemic diseases, a majority of the subjects (65\%) were found to have halitosis as a result of systemic disease. Figure 3 shows the results of the related question.

A few ratios of the subjects (19\%) declared that oral symptoms were not significant in the early diagnosis of systemic disease. $41 \%$ had the opposite answer, and $40 \%$ had no idea about the issue. In addition, $24 \%$ of the subjects specified that systemic diseases could not affect dental treatments, while $45 \%$ declared the contrary. Figure 4 summarizes subjects' answers on their awareness of the oral-systemic health relation.

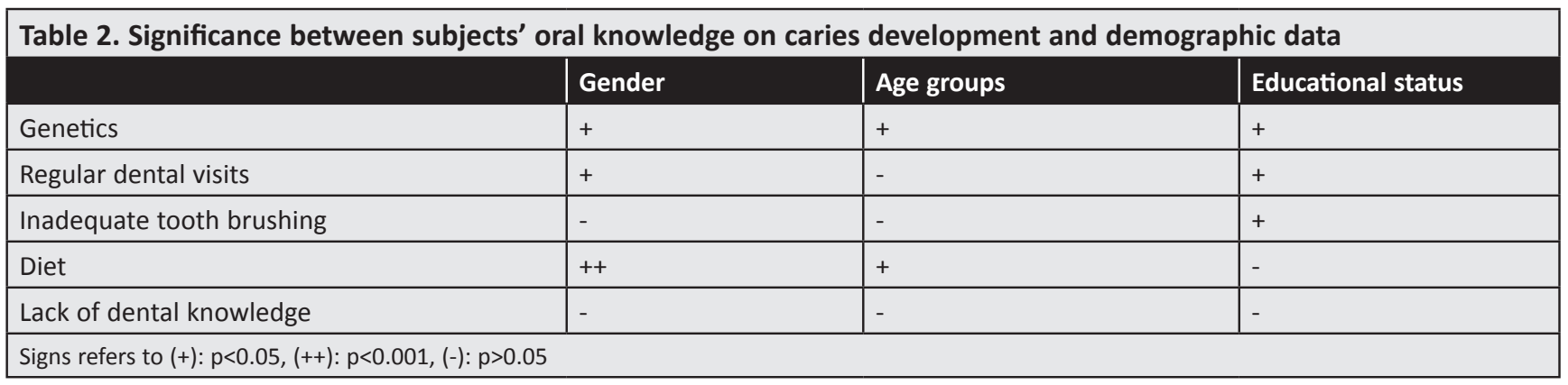

\section{Table 3. Subjects' systemic diseases and habits}

\begin{tabular}{|l|l|l|}
\hline Diseases/habits & No. of participants & Ratio among all participants \\
\hline Cardiovascular diseases & 45 & $9 \%$ \\
\hline Thyroid disorders & 15 & $3 \%$ \\
\hline Respiratory system diseases & 13 & $2.6 \%$ \\
\hline Rheumatic diseases & 54 & $10.8 \%$ \\
\hline Diabetes & 53 & $10.6 \%$ \\
\hline Anemia & 70 & $14 \%$ \\
\hline Hypertension & 27 & $5.4 \%$ \\
\hline Tobacco and/or alcohol use & 149 & $29.8 \%$ \\
\hline
\end{tabular}


In terms of age and gender, there was no statistically significant difference in subjects' awareness of the oral-systemic health relation $(p=0.113)$, but there was a statistically significant difference among subjects' educational status $(p<0.05)$.

\section{Discussion}

As oral health is an inseparable part of systemic health, it is obvious that chronic problems in the oral environment could cause a systemic effect. Thus, by fulfilling oral habits, ideally with optimum knowledge on oral diseases, a healthy systemic condition can be reached. It is important for every individual of the public to consider the relation between oral and systemic health and to reach out to available health services. Using a 21-item survey, the present study assessed the oral behavior, knowledge, and perception of the 500 patients who were willing to attend a dental service. The present study showed that the knowledge on factors of dental caries changed significantly regarding participants' gender, age, and

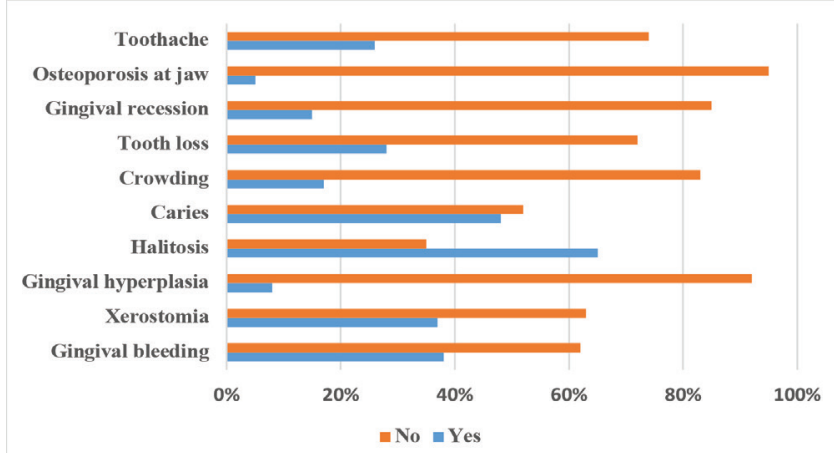

Figure 3. Subjects' knowledge on the oral symptoms of systemic diseases

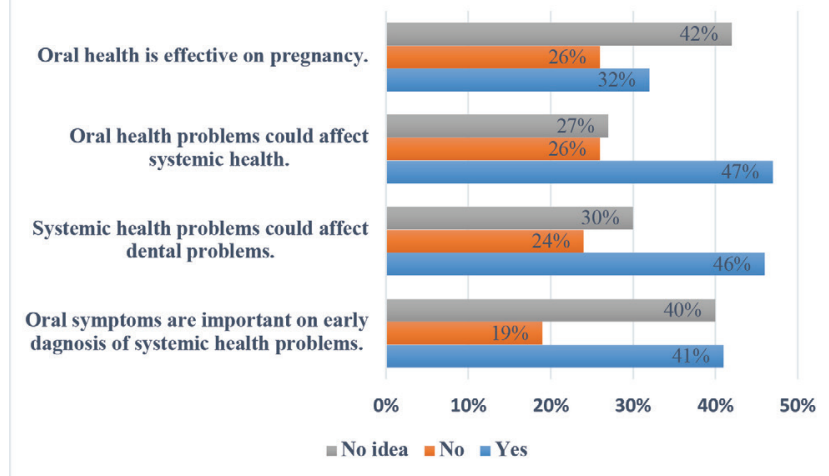

Figure 4. Subjects' awareness on the relation between oral and systemic health educational status. Therefore, the first hypothesis is rejected.

When evaluating the oral knowledge on caries development, the most common factor leading to caries development was tooth brushing. Even though subjects knew that a lack of tooth brushing caused caries development, they did not practice proper oral habits. Thus, knowledge about the risk of a disease does not always integrate into habitual behavior. Studies evaluating this issue were mainly focused on the knowledge of periodontal diseases of diabetic patients (14-18). However, there are a few studies $(18,19)$ evaluating patients' opinions on the risk factors of caries development. So, the present study is among the rare few investigating patients' knowledge on the factors causing dental caries.

Of the factors causing caries development, tooth brushing (70.6\%) and diet (50.2\%) were common answers among subjects. With a high percentage of knowledge on the effects of tooth brushing on caries development, the cause for the low ratio of tooth brushing among subjects was unclear. Furthermore, a diet consisting of refined carbohydrates and sugars had a crucial impact on bacterial nutrition and growth by increasing the acidic $\mathrm{pH}$ of oral cavities (20). Aside from this importance, nearly half of the subjects (49.8\%) described no relation between diet and caries development. Besides, routine dental visits were important to arrest white spot lesions that could be re-mineralized and to prevent caries progression. However, routine dental visits were thought not to be related with caries development among subjects (63.8\%). Moreover, dental knowledge was found to be irrelevant by most of the subjects (nearly $80 \%$ ); however, with a clinical examination among the subjects, caries prevalence would have been high. Tafere et al. (18) showed statistically and significantly lower caries prevalence among subjects with better knowledge of dental caries. In the related study, subjects fulfilling oral hygiene procedures were found to have statistically lower dental caries, and this would have been assumed in the present study as well. Another novel study by Francis et al. (19) showed that oral knowledge on both the cause and prevention of dental caries had a statistically significant increase among age. Although the mentioned study was conducted among high school students aged between 16 and 18, regarding whether subjects could learn 
from lessons in schools, the present study had the same result among adults as well. Having optimum oral knowledge could allow the public to improve oral habits and behaviors as well as lower the incidence of dental caries in future generations.

As the connection between oral and systemic health has been proven recently, it is not only physicians' but also dentists' responsibility to popularize the scientific data and inform patients. In addition, such responsibility is important to form proper oral habits and to be knowledgeable about oral hazards. 55.4\% of all subjects had at least one systemic disease, and nearly $30 \%$ of the subjects used tobacco or alcohol. Unfortunately, only one-fourth (1/4) of the diseased subjects were under physicians' control and took regular medicines daily. It is clear from the results that subjects were neither interested in their oral health nor their systemic health. Since subjects had inadequate knowledge of the probable oral symptoms of systemic diseases, the ratio of halitosis (65\%) was superior to others' symptoms such as caries (47.6\%). Also, it is obvious from the results that most of the subjects had inadequate knowledge of the oral and systemic relation. Diabetes was prevalent among subjects $(10.6 \%)$, and its relation between periodontal diseases was obvious; still, subjects did not relate either gingival bleeding $(37.8 \%)$ or gingival recession (15.4\%) as a symptom for diabetes. It should be taken into consideration that both physicians and dentists have a role in misguiding patients. In particular, physicians should direct patients with systemic diseases or habits to dentists immediately after the diagnosis or first appointment. The opposite is valid for dentists if the systemically ill patients' oral health status becomes worse. In the present study, educational status was shown to have a positive correlation with subjects' awareness of the oral and systemic health relation, similar to Shanmukappa et al.'s (17) and Tafere et al.'s (18) studies. It was clear from the results that a high amount of ratios were taken from subjects with "no idea". Subjects lacked knowledge; however, it could be concluded that consideration for the oral and systemic health relation existed among subjects. At most, pregnancy seemed to be linked with altered oral health among subjects. This part of the answers could be related to the higher educated portion of the subjects. That is why only the differences between participants' educational status had statistical significance in the perception of the oral and systemic health relation; thus, the present study's second hypothesis is partially accepted. When the educational status is increased, the awareness of oral and systemic health is higher. In addition, when the educational status is higher, subjects thought of more factors affecting dental caries such as genetics and dental visits, apart from the common answer of tooth brushing. In a study (21) conducted among 450 practitioners, dentists described that their knowledge on the influence of systemic diseases on oral health is inadequate. On the other hand, some studies $(6,22)$ also showed that physicians recognize the importance of oral health; however, they had a deficient perception of the effect of oral health on their systemic health. Thus, a common approach should be adopted by both physicians and dentists in order to guide systemically diseased patients.

The findings on oral behavior showed the inadequate application of oral hygiene habits such as brushing and flossing. A majority of subjects brushed their teeth once a day (48\%), and only $14 \%$ flossed. Even if the recommended brushing frequency is twice a day (23), only one-third of the subjects (35\%) followed the general recommendation. In accordance and in contrast to the present study, several studies have evaluated the oral habits of the population conducted in many countries. In Nigerian studies (24) with more than 7,600 responders and in South American studies (25) with more than 1,600 responders, nearly $50 \%$ practiced tooth brushing twice a day. Although only $10.5 \%$ of Nigerian responders flossed, which was similar to the ratio of the present study, there were still more brushers than flossers. In a study (26) conducted in Italy with 2,200 adults aged between 18 and 98 , more than $70 \%$ of the responders brushed once a day, and this was superior to the present study's results (48\%); however, it showed the same flossing ratio. It is obvious from the different studies' scores that subjects brush their teeth more than they floss. The present study detected that $9 \%$ brushed irregularly and $2 \%$ had never brushed before. A higher ratio was described in the Iranian population of 12,105 responders, with $32.5 \%$ having never brushed and $83 \%$ having never flossed (27). Although the size of respondents varied in many studies and the ratios changed with the participants' age, gender, and educational status, as well as the 
country's socioeconomic level $(24,25,28)$, the ratio of ideal oral habits was low. Despite lacking oral hygiene procedures, subjects also demonstrated challenges meeting regular dental visits. Routine dental visits are important for early diagnosis of oral problems; also, if a systemic disease such as diabetes is present, it is crucial to detect oral lesions at their early stages (29). For the ratios of one dental visit a year, studies (30) from Germany (60\%), Ireland (44\%), and Spain (27\%) showed superior results compared to the present study's subjects (14\%). Furthermore, nearly half of the subjects (46.6\%) had a toothache in the last 6 months, and half had spontaneous gingival bleeding (44.6\%). Without fulfilling regular oral hygiene procedures, most of the oral problems become expectable. It is obvious that not only spontaneous gingival bleeding but also probable caries that lead to toothaches could simply be prevented by regular brushing. However, subjects showed inadequate oral habits, revealed excessive oral problems, and described rare dental visits. Therefore, it was clear that subjects were only applying to emergency clinics when there was a chronic oral problem or a toothache. Among all, subjects tend to rely on their own choices when selecting toothpastes rather than the dentists' recommendations. Beginning with university clinics, a nationwide approach should be taken to generalize the significance of oral hygiene procedures. In addition, oral health promotions of universities or public clinics should be easily accessible for all patients.

\section{Conclusion}

Subjects of the present study had inadequate knowledge about both caries development and the oral and systemic health relation. In addition, it was obvious that subjects had an unfavorable interest in oral hygiene habits. There should be a mutual relationship between patients and dentists in improving patients' oral health knowledge and behaviors. Patients should learn the etiologies of not only dental diseases but also the outcomes of systemic conditions on dental tissues; also, dentists should be trained to provide oral habits education. The public should learn where to access dental information or refer to a dental specialist on routine recalls and/or daily practices.
Common guidelines should be developed with medical organizations in order to inform systemically ill patients and to warn them about probable dental complications. To add more, academic institutions should educate on the value of scientific research and the oral and systemic health relation so that both medical and dental students can put these principles into practice.

\section{Ethics}

Ethics Committee Approval: The present cohort study was designed as a survey and was approved by the Clinical Research Ethics Committee of İstanbul University i̇stanbul Faculty of Medicine (decision no: 416, date: 16.04.2013).

Informed Consent: Written consents from participants had taken and kept in files separated for each one.

Peer-review: Externally and internally peerreviewed.

\section{Authorship Contributions}

Concept: U.E., G.O., Design: U.E., Supervision: U.E., G.O., Fundings: U.E., G.O., L.E.G., E.Y., Materials: G.O., L.E.G., Data Collection or Processing: G.O., L.E.G., Analysis or Interpretation: E.Y., Literature Search: U.E., E.Y., G.O., L.E.G., Writing: U.E., G.O., L.E.G., E.Y., Critical Review: E.Y., U.E.

Conflict of Interest: No conflict of interest was declared by the authors.

Financial Disclosure: The authors declared that this study received no financial support.

\section{References}

1. Phantumvanit $P$, Makino $Y$, Ogawa $H$, Rugg-Gunn A, Moynihan P, Petersen PE, et al. WHO Global Consultation on Public Health Intervention against Early Childhood Caries. Community Dent Oral Epidemiol 2018; 46: 280-7.

2. lida $H$, Auinger $P$, Billings RJ, Weitzman M. Association between infant breastfeeding and early childhood caries in the United States. Pediatrics 2007; 120: e944-52.

3. Gokalp S, Dogan BG, Tekcicek M, Berberoglu A, Unluer S. The oral health profile of adults and elderly, Turkey-2004. J Hacettepe Fac of Dent 2007; 31: 11-8.

4. Istanbul Declaration of FDI 2013. Available from URL: https:// www.fdiworlddental.org/what-we-do/advocacy/declarations/ istanbul-declaration.

5. Glick M, Williams DM, Kleinman DV, Vujicic M, Watt RG, Weyant RJ. A new definition for oral health developed by the FDI World 
Dental Federation opens the door to a universal definition of oral health. Int Dent J 2016; 66: 322-4.

6. Opeodu OI, Ogunrinde TJ, Fasunla AJ. An assessment of medical doctors' perception of possible interrelationship between oral and general health. Eur J Gen Dent 2014; 3: 120-4.

7. Mosley M, Offenbacher S, Phillips C, Granger C, Wilder RS. North Carolina Cardiologists' Knowledge, Opinions and Practice Behaviors Regarding the Relationship between Periodontal Disease and Cardiovascular Disease. J Dent Hyg 2015; 89 Suppl 2: 38-48.

8. Gavaza P, Rogers T, Mosavin R. California Dentists' Opinions of the Interface Between Oral and Overall Health. J Calif Dent Assoc 2017; 45: 85-91.

9. Dietrich $T$, Webb I, Stenhouse L, Pattni A, Ready D, Wanyonyi $\mathrm{KL}$, et al. Evidence summary: the relationship between oral and cardiovascular disease. Br Dent J 2017; 222: 381-5.

10. D'Aiuto F, Gable D, Syed Z, Allen Y, Wanyonyi KL, White S, et al. Evidence summary: The relationship between oral diseases and diabetes. Br Dent J 2017; 222: 944-8.

11. Hashimoto $H$, Hashimoto $S$, Muto A, Dewake N, Shimazaki $Y$. Influence of plaque control on the relationship between rheumatoid arthritis and periodontal health status among Japanese rheumatoid arthritis patients. J Periodontol 2018; 89: 1033-42.

12. Manger D, Walshaw M, Fitzgerald R, Doughty J, Wanyonyi KL, White $\mathrm{S}$, et al. Evidence summary: the relationship between oral health and pulmonary disease. Br Dent J 2017; 222: 527-33.

13. Shen TC, Chang PY, Lin CL, Chen $\mathrm{CH}$, Tu CY, Hsia TC, et al. Risk of Periodontal Diseases in Patients With Chronic Obstructive Pulmonary Disease: A Nationwide Population-based Cohort Study. Medicine (Baltimore) 2015; 94: e2047.

14. Taşdemir Z, Alkan BA. Knowledge of medical doctors in Turkey about the relationship between periodontal disease and systemic health. Braz Oral Res 2015; 29: 55.

15. Ueno M, Takeuchi S, Oshiro A, Shinada K, Ohara S, Kawaguchi Y. Association between diabetes mellitus and oral health status in Japanese adults. Int J Oral Sci 2010; 2: 82-9.

16. Akyuz S, Yarat A, Bayer H, Ipbuker A. Diabetic patient's knowledge level on oral health and habits (questionnaire). OHDMBSC 2004; 3: 11-4.

17. Shanmukappa SM, Nadig P, Puttannavar R, Ambareen Z, Gowda TM, Mehta DS. Knowledge, Attitude, and Awareness among Diabetic Patients in Davangere about the Association between Diabetes and Periodontal Disease. J Int Soc Prev Community Dent 2017; 7: 381-8.

18. Tafere $\mathrm{Y}$, Chanie S, Dessie T, Gedamu H. Assessment of prevalence of dental caries and the associated factors among patients attending dental clinic in Debre Tabor general hospital: a hospital-based cross-sectional study. BMC Oral Health 2018; 18: 119.

19. Francis DL, Balasubramanian KR, Durga $R$, Chandran CR. Knowledge about causes and prevention of oral diseases among higher secondary school students in Vellore District, Tamil Nadu, India: A cross-sectional survey. J Indian Assoc Public Health Dent 2018; 16 : 231-5.

20. Decker RT. Sugars and dental caries. Am J Clin Nutr 2003; 78 : 881S-92.

21. Song $M, O^{\prime}$ Donnell JA, Bekhuis T, Spallek H. Are dentists interested in the oral-systemic disease connection? A qualitative study of an online community of 450 practitioners. BMC Oral Health 2013; 13: 65.

22. Gavaza P, Kim W, Mosavin R, Ta N. California physicians' opinions of the interface between oral and overall health: a preliminary study. J Farm Med Dis Prev 2015; 1: 20-5.

23. Al-Ansari J, Honkala E, Honkala S. Oral health knowledge and behavior among male health sciences college students in Kuwait. BMC Oral Health 2003; 3: 2.

24. Olusile AO, Adeniyi AA, Orebanjo O. Self-rated oral health status, oral health service utilization, and oral hygiene practices among adult Nigerians. BMC Oral Health 2014; 14: 140.

25. Gómez MV, Toledo A, Carvajal P, Gomes SC, Costa RSA, Solanes $F$, et al. A multicenter study of oral health behavior among adult subjects from three South American cities. Braz Oral Res 2018; 32: e22.

26. Villa $A$, Kreimer AR, Polimeni A, Cicciù D, Strohmenger L, Gherlone $\mathrm{E}$, et al. Self-reported oral hygiene habits among dental patients in Italy. Med Princ Pract 2012; 21: 452-6.

27. Asgari F, Majidi A, Koohpayehzadeh J, Etemad K, Rafei A. Oral hygiene status in a general population of Iran, 2011: a key lifestyle marker in relation to common risk factors of non-communicable diseases. Int J Health Policy Manag 2015; 4: 343-52.

28. Crocombe LA, Brennan DS, Slade GD, Loc DO. Is self interdental cleaning associated with dental plaque levels, dental calculus, gingivitis and periodontal disease? J Periodontal Res 2012; 47: 188-97.

29. Centers for Disease Control and Prevention. Working Together to Manage Diabetes: A Guide for Pharmacists, Podiatrists, Optometrists, and Dental Professionals. Atlanta, GA: US Department of Health and Human Services 2007. Available from URL: http://ndep.nih.gov/media/PPODprimer_color.pdf.

30. Christensen LB, Petersen PE, Steding-Jessen M. Consumption of dental services among adults in Denmark 1994-2003. Eur J Oral Sci 2007; 115: 174-9. 


\section{Appendix 1: The questionnaire of oral knowledge, oral habits and perception}
1. Age:
2. Gender: Women

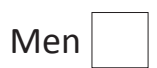

3. Neighborhood:

4. Educational status:
a) Primary
b) Middle school
c) High school
d) University/college
e) None

5. Do you have health insurance?
a) SGK
b) Retirement fund
c) Private insurance
d) Med-nased insurance
e) None

6 . How many times do your brush your teeth?
a) Once a day
b) 2-3 times a day
c) Once a week
d) Irregular e) None

7. Do you have the habit of flossing?
a) Yes
b) No

8. Do you follow your dental recalls?
a) Yes
b) No

9. Did you have ever gum bleeding in the last 6 months?
a) Yes
b) No

10. Did you have ever toothache in the last 6 months?
a) Yes
b) No

11. Did you ever have tooth scaling in the last 6 months?
a) Yes
b) No
c) No idea

12. What is the leading factor on your decision on choosing toothbrush and toothpaste?
a) Advertisements
b) My dentists opinion
c) Price
d) My own experience

13. What is/are the factor/-s that affects caries development?
a) Diet
b) Toothbrushing
c) Recalls
d) Lack of oral knowledge
e) Genetics

14. Do you have one or more of the below-mentioned conditions or diseases?
a) Cardiovascular diseases
b) Thyroid diseases (Such as goiter)
c) Pulmonary diseases (Such as bronchitis, asthma)
d) Rheumatic diseases
e) Diabetes (Type I or II)
f) Anemia
g) Multiple sclerosis 
h) Hypertension

i) Neurological diseases (Such as Parkinson's, stroke)

j) Epilepsia

k) Chronical kidney failure

l) Alcohol/Tobacco use

m) Others

15. If you have any of the above-mentioned conditions/diseases, is it under control of your physician?
a) Yes
b) No

16. Do you use a drug/medicament regularly?
a) Yes
b) No

17. Which of the following /-s could be seen in individuals dealing with a systemic disease?

a) Gum bleeding while brushing

b) Halitosis

c) Xerostomia

d) Gingival hyperplasia

e) Dental caries

f) Teeth loss

g) Gingival recession

h) Osteoporosis at jaw

i) Toothache

j) Malocclusion

18. Do you think that the oral symptoms could play a role on the early diagnosis of systemic diseases?
a) Yes
b) No
c) No idea

19. Do you think that systemic diseases could affect oral environment?
a) Yes
b) No
c) No idea

20) Do you think that systemic diseases could affect your dental treatments?
a) Yes
b) No
c) No idea

21) Do you think that any oral problem could affect your systemic health?
a) Yes
b) No
c) No idea

22. Do you think that any oral problem could affect pregnancy?
a) Yes
b) No
c) No idea 